\title{
An unusual case of neck pains: medullary thyroid carcinoma
}

\author{
Vinuta Mohan, ${ }^{1}$ Chikezie Konde Alvarez ${ }^{\oplus 1,2}$
}

'Department of Medicine, Saint Francis Medical Center, Trenton, New Jersey, USA

${ }^{2}$ Department of Internal Medicine, School of Health and Medical Sciences, Seton Hall University, South Orange, New Jersey, USA

\section{Correspondence to}

Vinuta Mohan,

vmohan@stfrancismedical.org

Accepted 11 June 2019

\section{DESCRIPTION}

A 60-year-old African man with a history of hypertension, hypercholesterolaemia and coronary artery disease presented to our emergency room complaining of approximately 1-2 weeks of neck pains radiating to his chest. The pains were associated with movement, particularly when he moved his head and neck. His social and family history were unremarkable. Other than his presenting symptoms, his review of symptoms was negative. His blood pressure was $126 / 67 \mathrm{~mm} \mathrm{Hg}$ and his pulse was 88 beats/min.

Cardiac, pulmonary, neurology and extremity exams were all within normal limits. He underwent chest CT which revealed no significant cardiac or pulmonary disease. However, a large ill-defined $4 \mathrm{~cm}$ right thyroid nodule was noted, associated with tracheal deviation at the thoracic inlet (figure 1). Thyroid ultrasound confirmed an enlarged right lobe with an approximately $4 \mathrm{~cm}$ heterogeneous nodule with microcalcifications (figure 2). The left lobe was unremarkable. A firm right thyroid nodule was subsequently confirmed on exam. The patient denied any personal or family history of thyroid nodules or thyroid disease. $\mathrm{He}$ denied any dysphagia, respiratory difficulties or changes in voice. Thyroid stimulating hormone was normal at $1.18 \mathrm{mIU} / \mathrm{ml}$. The patient was referred for fine needle aspiration of the thyroid nodule which confirmed the presence of Hurtle cells and suspicion for follicular neoplasm. The patient underwent a right hemithyroidectomy and was found to have a unifocal $5 \mathrm{~cm}$ medullary thyroid carcinoma with negative margins and no evidence of extrathyroidal extension or lymphatic invasion. H\&E staining was positive for nests of tumour cells and staining was also positive for calcitonin (figures 3 and 4). $\mathrm{He}$ underwent further serum testing including parathyroid hormone (PTH), calcium and plasma metanephrines which were all within normal limits.

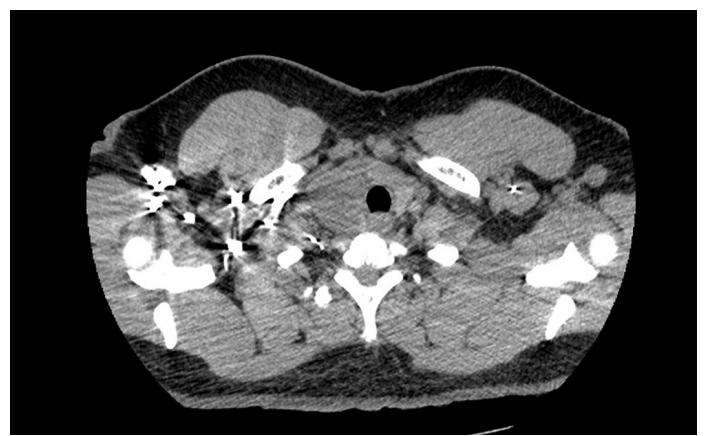

Figure 1 CT scan showing tracheal deviation.

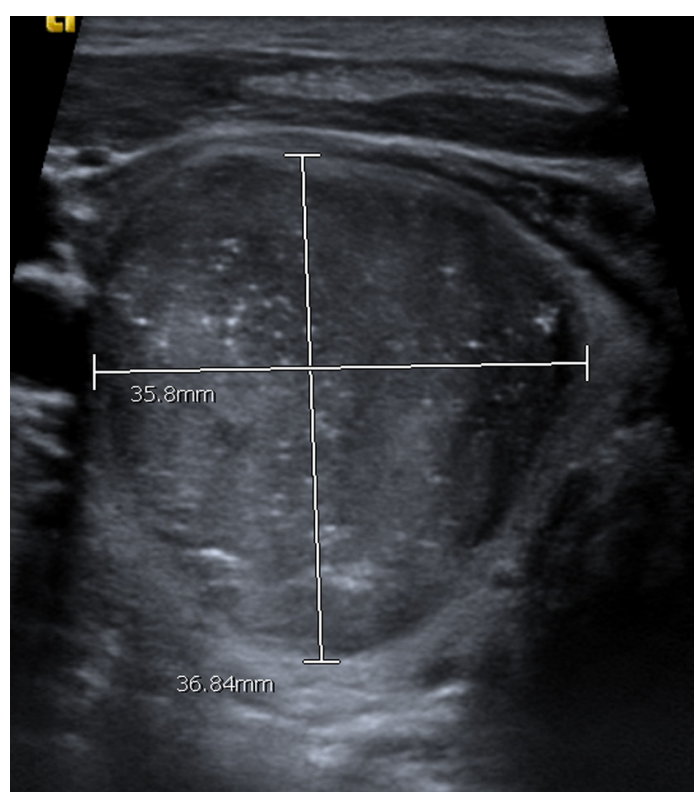

Figure 2 Right lobe of thyroid with dominant nodule.

Screening for RET protooncogene mutations was negative. He underwent completion thyroidectomy and central neck dissection. Postoperative calcitonin was less than $2 \mathrm{pg} / \mathrm{mL}$ and carcinoembryonic antigen was less than $2 \mathrm{ng} / \mathrm{mL}$. His left thyroid lobe and lymph nodes were negative for malignancy and he is currently euthyroid on levothyroxine therapy.

Medullary thyroid cancer (MTC) is uncommon and accounts for only 1\%-2\% of all thyroid cancers.

It is a malignancy of the parafollicular thyroid C cells that secrete calcitonin, and usually presents between the fourth and sixth decade of life. Although more than $80 \%$ of cases of MTC are sporadic, some may be due to germline mutations in the RET protooncogene resulting in hereditary MTC. Hereditary MTC can be seen as part of multiple endocrine neoplasia type $2 \mathrm{~A}$ or $2 \mathrm{~B}$, or as part of familial medullary thyroid cancer. The RET protooncogene is located on chromosome 10q11.2 and encodes a transmembrane receptor of the tyrosine kinase family. Virtually all patients with hereditary MTC have RET mutations in exons 10, 11, 13, 14, 15 or $16 .{ }^{1}$ Hereditary MTC has an autosomal dominant mode of inheritance. Therefore, patients who test positive are strongly advised to have targeted family members tested. Our patient's RET gene was analysed and coding exons 1-20 were tested with negative results. Although there is a chance he carries a mutation elsewhere in this gene, his personal history of MTC is likely sporadic so genetic testing for his family was not recommended. 


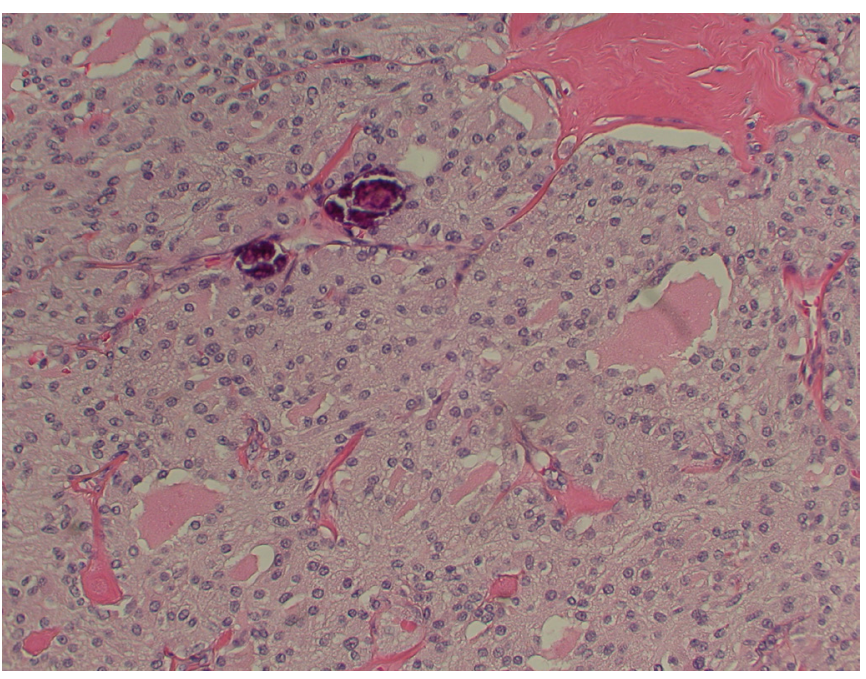

Figure 3 H\&E stain $(\times 200)$ showing nests of tumour cells.

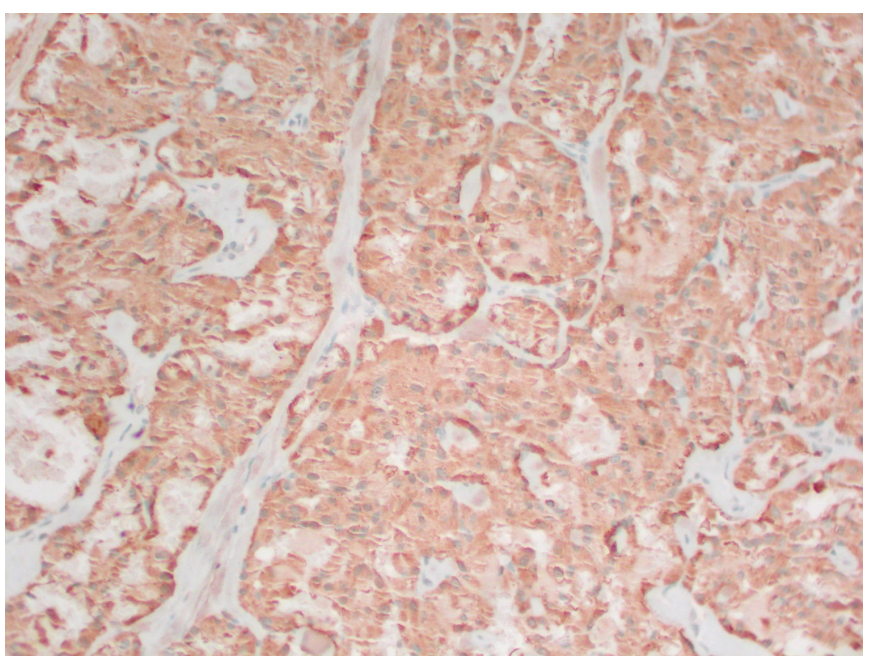

Figure 4 Calcitonin stain $(\times 200)$

\section{Learning points}

- When patients present with neck pains, a thorough, focused physical exam should be performed.

- When a case of medullary thyroid cancer is found, it is important to do further testing to determine if the case is sporadic or associated with hereditary disease by testing for RET protooncogene mutations.

- Patients who test positive for the RET oncogene should be referred to specialty clinics; their family members should be tested and educated about the disease as well as its prevention.

MTC tumours are usually located in the posterior thyroid and may compress or invade local structures causing symptoms of pain, hoarseness, dysphagia or respiratory difficulties. Fifty to seventy per cent of patients with MTC who present with a palpable thyroid nodule have cervical metastases and $10 \%$ have distant metastases. Treatment entails a minimum of a total thyroidectomy and bilateral central neck dissection. ${ }^{2}$ Our patient was very fortunate; his MTC was localised only to his right lobe with no evidence of local or distant metastasis, unusual for palpable MTC.

Contributors VM is the corresponding and primary author of this article. CKA contributed with formatting and imaging.

Funding The authors have not declared a specific grant for this research from any funding agency in the public, commercial or not-for-profit sectors.

Competing interests None declared.

Patient consent for publication Obtained.

Provenance and peer review Not commissioned; externally peer reviewed.

\section{REFERENCES}

1 Wells SA, Asa SL, Dralle H, et al. Revised American Thyroid Association guidelines for the management of medullary thyroid carcinoma. Thyroid 2015:25:567-610.

2 Sippel RS, Kunnimalaiyaan $\mathrm{M}, \mathrm{Chen} \mathrm{H}$. Current management of medullary thyroid cancer. Oncologist 2008;13:539-47.

Copyright 2019 BMJ Publishing Group. All rights reserved. For permission to reuse any of this content visit

https://www.bmj.com/company/products-services/rights-and-licensing/permissions/

BMJ Case Report Fellows may re-use this article for personal use and teaching without any further permission.

Become a Fellow of BMJ Case Reports today and you can:

- Submit as many cases as you like

- Enjoy fast sympathetic peer review and rapid publication of accepted articles

- Access all the published articles

Re-use any of the published material for personal use and teaching without further permission

Customer Service

If you have any further queries about your subscription, please contact our customer services team on +44 (0) 2071111105 or via email at support@bmj.com.

Visit casereports.bmj.com for more articles like this and to become a Fellow 